9.

\title{
Music during the Cold War: A Romanian story
}

\author{
Florinela Popa
}

After WWII, Romania found itself in the sphere of influence of the Soviet Union and became a member of the Warsaw Pact in 1955. As such, the country was involved in the Cold War from 1948 to 1989. In this context, its foreign policy went through several stages, which can also be observed at the level of music both in the diplomatic relations it cultivated and in the research produced in Romania. The first phase was characterized by the total subordination to Moscow, the striving toward establishing a "union of brotherly nations" with other "people's democracies". In the second phase, Romania distanced itself from the USSR, and the third phase was one of international isolation.

\section{Phase 1}

The conditions under which Romania finished WWII-unexpectedly switching sides to the Allies at the last minute and being "liberated" by the Red Army-rendered inevitable its positioning within the Soviet Bloc. After becoming a people's republic led by a single party (the Romanian Workers' Party) on December 10, 1947, Romania signed on 4 February, 1948 a Treaty of Friendship, Collaboration and Mutual Assistance with the Soviet Union, ${ }^{1}$ thus firmly distancing itself from the West and relinquishing any assistance the Marshall Plan might have offered.

The faithful copying of the Soviet model and the virulent pro-Soviet propaganda pushed Romania toward totalitarianism at full speed. As all other sectors of Romanian cultural life, music also entered the grinder of Sovietization: musical institutions were reorganized and subjected to political control, formalist tendencies in music were "exposed," and musicians' diplomatic relations had to conform to the country's foreign policy.

The Muzica journal, turned into the regime's mouthpiece in 1950, testifies to the intense exchanges with the Soviet Union in particular, but also with Bulgaria, the German Democratic Republic, Hungary, Czechoslovakia, the Ukrainian Soviet Socialist Republic and the Moldavian Soviet Socialist Republic. Following the

1 Dennis Deletant, "România sub regimul comunist (decembrie 1947-decembrie 1989) [Romania under Communist Rule (December 1947-December 1989)]," in Istoria României, edited by M. Bărbulescu et al. (Bucharest: Corint, 2012), 408. 
Tito-Stalin Split of 1948, not even a passing reference to Yugoslavia appeared in Muzica throughout the 1950s. During the heyday of Stalinism, international festivals were organized - such as the Romanian Music Week (1951), the Bulgarian Music Week (1952), or the Prague Spring International Music Festival (ongoing since 1946) - designed to connect musicians from "friendly countries."

Through the manner in which the press records such events, the power relations between the participants are plain to see: the musicians from the USSR enjoy a position of clear superiority, having the first and last word, praising and criticizing with equal impunity. Then there is the "brotherly" position, the position of "friendship" among apprentices from people's democracies, needing to be guided in the assimilation of Leninist-Stalinist teachings. The presence of any Western name-which is very rare anyway-is invariably accompanied by the designation "progressive" and presented as a sort of dissidence against capitalism. The implicit opposition of "friendly countries" versus "capitalist countries" leaves no room for even the tiniest doubt as to the official political line: "Composers from all over the country $[\ldots]$, representatives of friendly countries, and progressive artists from capitalist countries participated in the Romanian Music Week." 2

It is evident that the relations between Romanian and USSR musicians were marked by clear subservience, despite the professed "friendship" and "brotherhood." It is significant that the only musicians invited to lecture at the Romanian Composers' Union during the Romanian Music Week were members of the USSR delegation: Vladimir G. Zakharov, Vasily P. Solovyov-Sedoi and Alexander G. Arutiunian. Muzica published their heavily politically oriented talks in full, but no other foreign participants' impressions or perspectives.

Zakharov, for instance, criticized the poor representation of the "fight for peace" and "friendship between peoples" in the Romanian music of the time-two hot topics, suited to the position feigned by the USSR during the Cold War: "We didn't have the opportunity to listen to any great symphonic works dedicated to the fight for peace. We listened to too few works dedicated to the friendship between peoples, even if the motto of the week is Let us sing the peace and friendship between peoples."

The implications of the Cold War in music are also discernible in the picturesque speech given by Solovyov-Sedoi. Under the guise of a plea for the valorizing of folklore, he condemns Western music, recounting a most likely fictitious event which supposedly took place at the 1948 Second International Congress of Composers and Music Critics in Prague:

\footnotetext{
2 “Săptămâna Muzicii Românești [Romanian Music Week]," Muzica 5 (1952): 20.

3 Vladimir Grigoryevich Zakharov, "Cuvântarea compozitorului V.G. Zaharov ținută în ședința din 28.IX.1951 a Plenarei Uniunii Compozitorilor din R.P.R. [Composer V. G. Zakharov's Speech at the Meeting of September 28, 1915 of the Plenary of the Romanian People's Republic Composers' Union]," Muzica 5 (1952): 59-60.
} 
A Dutch musician uttered the following absurd phrase: "How are Dutch composers supposed to write music if there is no folk music in the Netherlands?"

I remember that the audience received these words with a somber silence. Indeed, it is difficult to imagine a nation without its own music. I believe that things are rather different. It's that Dutch musicologists study imported music and the music of their local composers, written in the likeness of that imported music or of the music they receive from capitalist countries in exchange for Dutch cheese, the principle being: a wheel of cheese for a little jazz song, whose sensationalist title reads Mary Likes the Smell of Cheese in Spring. But we, the composers from people's democracies and the composers from the Soviet Union, know very well that not peoples, but only politicians [from capitalist countries, $A / N$ ] prevent through all available means the peoples' national self-determination. ${ }^{4}$

The conclusion of this grotesque peroration is that "Romanian musicologists and composers do not need to import themes for their works." ${ }^{5}$

In the early 1950s, all Romanian musicians visiting the USSR wrote enthusiastically about the level reached by the Soviet musical establishment, and by Moscow in particular. More often than not, the discourse nevertheless degenerates into singing praise to Stalin, who comes to be seen not only as the leader of the Eastern Bloc, but as an embodiment of the ideal politician, for whom the whole world longs, including those under "subjugation" in the West:

Visiting the Museum with gifts to comrade Stalin and the Museum of the Revolution, I was able to realize once again that comrade Stalin is indeed the world's most beloved man. Hundreds of thousands of gifts from all countries of the world, among which are Austria, Spain, the Netherlands, Indonesia, Tunisia, Thailand, Iran, Lebanon, France, Brazil, Argentina, testify to the fervent love that simple people all over the world feel for the great leader of the Soviet people. 6

Between 1950 and 1953 in particular, artistic exchanges between Romanian musicians and those from other "friendly countries" intensified. In presenting such

4 Vasily Pavlovich Solovyov-Sedoi, "Cuvântarea compozitorului V.P. Soloviev-Sedoi ținută în ședința din 29.IX.1951 a Plenarei Uniunii Compozitorilor din R.P.R. [Composer V. P. SolovyovSedoi's speech at the meeting of September 28, 1915 of the Plenary of the Romanian People's Republic Composers' Union]," Muzica 5 (1952): 63-64.

5 Ibid.

6 Mauriciu Vescan, “Aspecte din viața muzicală a capitalei Uniunii Sovietice [Aspects of musical life in the capital of the Soviet Union]," Muzica 12 (1952): 146. 
events, the press highlighted their "political and cultural" 7 or "political and artistic" 8 significance. References to the Cold War even tainted speeches on children's artistic performances. The visit of the Kreuzchor children's ensemble from Dresden to Romania in 1952 was seen "as a materialization of the collective and brotherly efforts of the working people in the Romanian People's Republic and in the German Democratic Republic to join forces, collaborate and fight for the protection of peace and culture, threatened by American and English imperialists." 9

Beyond such slogans as "the fight for peace," most texts that emphatically support the "peace and friendship between peoples" allude to the "enemy" - the Western, capitalist, "imperialist" world. As a concession, only the (few) Western "progressive" musicians who are in contact with the Socialist Bloc and who might aspire to a life similar to the one in the Soviet Union are mentioned.

On the front page of the 12/1952 issue, Muzica published Stalin's answers to a New York Times correspondent on the Cold War. To the question as to where the international tensions originated, Stalin answered: "Everywhere and anywhere the aggressive actions of the 'cold war' policy against the Soviet Union show themselves." 10 The no less aggressive policy of the Soviet Union and its satellite states can be deduced even from ordinary texts on music, whose leitmotif is the "peace and friendship between peoples."

A common denominator of the attitude toward the West is the demonization of Anglo-American imperialism, the ever-present enemy, guilty, for example, of the deepening cultural rupture between East and West Germany, as is apparent from several texts on music published in the GDR. Here is an example:

The new Germany weaves its song with the fight for freedom from the tyranny of Anglo-American imperialism. Just as highways, like asphalt rivers, regularly display large posters featuring cartoons-hilarious ones at that-addressing the Yankees who will not leave with the famous "Go home," the people have their cherished melody, quivering on the lips of all free Germans, the well-known Go home, with an ironic syncopated rhythm chorus: "Go home, Yank! Yank, go home! Say goodbye to father Rhine."11

\footnotetext{
7 See Vasile Cristian, "Soli ai muzicii din țările prietene [Heralds of Music from Friendly Countries]," Muzica 9 (1952): 84.

8 See Hilda Jerea, "Festivalul muzicii bulgare [Bulgarian Music Festival]," Muzica 9 (1952): 97.

9 Cristian, "Soli ai muzicii din țările prietene," 85.

${ }^{10}$ Joseph Vissarionovich Stalin, "Răspunsurile tovarășului I. V. Stalin la întrebările primite din partea corespondentului diplomatic al lui New York Times, James Reston, la 21 decembrie 1952 [Comrade's J. V. Stalin's Answers to the Questions of the New York Times Diplomatic Correspondent James Reston from December 21, 1952]," Muzica 12 (1952): 9.

11 Virgil Gheorghiu, "Impresii din Republica Democrată Germană [Impressions from the German Democratic Republic]," Muzica 12 (1952): 148.
} 
The author of the article recounts the success Romanian baritone Octav Enigărescu apparently enjoyed with this song at sold-out performances in Dresden, Berlin and Erfurt: "You could tell that the German wishes with all his heart that the uninvited guests would leave, that he is anxious to preserve peace, and that he will know how to defend it at all times and at all costs." ${ }^{12}$ Such comments are hard to believe, especially since East Germany had been a Moscow's satellite state and under strict control of the Soviets for three years. Therefore, the "uninvited guests" could not have been the Americans.

The dissatisfaction with "Anglo-American imperialists" allegedly expressed by a West German conductor in the very city of Berlin cast, yet again, a somber shadow over West Germany. The name of the conductor is omitted although his words are given as a quotation. With this in mind, we may assume that both the conductor and his remark were invented:

I remember how a West German conductor, wanting to meet the delegation of Romanian artists, approached us in Berlin and said: "I am an apolitical man, but I want to perform the music of my country. The Anglo-American imperialists will not allow it. Beethoven's Fidelio, Mozart's Le nozze di Figaro are very rarely performed. Instead, decadent ballets and jazz music abound." 13

The 1952 Prague Spring International Music Festival also provided fruitful material for anti-Capitalist tirades. Considerable international participation of musicians from both the East and the West occasioned composer Alfred Mendelsohn to play the two worlds off against each other in his article "Impressions from Prague." In it, he makes a clear distinction between the "Socialist state, supporter of the arts and artists, and the capitalist state, the enemy of true art and progressive artists." 14 Notwithstanding these claims, the composer proceeds to deny the existence of the Iron Curtain, claiming it is an invention of the "scheming Anglo-Americans":

Musicologists and performers from Capitalist countries will be able to bring to the working class and the progressive strata from their countries the message of love and trust of the builders of Socialism, the testimony of a brotherly welcome and of the high level in composition and performance, from here where the proletariat is in power. They will help in dispelling the stupid lie put forth by the scheming Anglo-Americans about the alleged "iron curtain." Between the people deeply convinced of the importance of the fight for peace and of the fight against all oppression and crime committed against peaceful nations, there is no iron curtain. ${ }^{15}$

\footnotetext{
12 Ibid.

13 Ibid., 149.

14 Alfred Mendelsohn, “Impresii din Praga [Impressions from Prague],” Muzica 9 (1952): 104.

15 Ibid., 106.
} 
Soviet propaganda went even further, exploiting the "enemy's" every weakness, real or invented. The insinuation, for instance, that English musicians would begin craving a cultural life similar to that in the East-in a Muzica article titled "English Musicians' Fight for Peace" - is hilarious, at the very least:

The economic crisis in England caused by governmental policy on armament burdens the English musicians' lives as well. Concerts are ever rarer, many philharmonic halls close their gates, as the funds allotted by the state to cultural necessities are heavily reduced [...]. English musicians begin to understand that the development of musical art is only possible in an era of true peace, of durable peace won through the joint fight of all peoples. ${ }^{16}$

Another news article, one on American composers being censored at home, without being a fiction of Soviet propaganda, reflects the vulnerability experienced in the West for about a decade by the threat posed by the Soviet Union. Unfortunately, the Communist witch-hunt in the US beginning in the late 1940s due to tensions engendered by the Cold War was quite close to the terror instituted in the Eastern Bloc for a while:

The works of seven renowned American composers were termed "subversive" and banned on the order of McCarthy, ${ }^{17}$ the author of the wellknown violent measures. The seven composers are: George Gershwin, Aaron Copland, Leonard Bernstein, Roy Harris, Randall Thompson, Virgil Thomson and Roger Sessions. Aaron Copland [...] attracted McCarthy's ire by dedicating one of his works to Abraham Lincoln, ${ }^{18}$ and Roy Harris by writing a symphony called the "Stalingrad Symphony"19 inspired by the Soviet Army's historical victory at Stalingrad. 20

This extremely dark phase of the Cold War, in which Romania was also trapped, left a visible mark on the establishment of diplomatic relations through music. Romanian output of the time could not evade Sovietization. Also relevant is

\footnotetext{
16 “Din alte țări [From Other Countries]," Muzica 2 (1953): 76-77.

17 Joseph Raymond McCarthy (1908-1957), American politician, Republican Senator for Wisconsin between 1947 and 1957. In a time when Cold-War tensions fed the fears of Americans who worried about a possible substantial Communist subversion, McCarthy was extremely active in preventing the spread of Communism to the US. He is known for his accusations (many of them false) with regard to several Soviet and Communist spies infiltrating the US government, universities, the film industry, etc. ${ }^{18}$ Lincoln Portrait (1942) for narrator and orchestra.

19 The information is inaccurate. The author is in fact talking about Symphony No. 5 (1942), untitled but dedicated "to the heroic and freedom-loving people of our great ally, the Union of Soviet Socialist Republics." See https://www.naxos.com/catalogue/item.asp?item_code $=8.559609$, accessed August 26, 2020.

20 "Din alte țări," 77.
} 
the immense quantity of works dedicated to Stalin or to the "peace and friendship between peoples." 21

\section{Phase 2}

After Stalin's death, Romania took at first tentative, then increasingly steadfast steps toward autonomy from Moscow. As part of the Warsaw Pact, Romania was involved in the Hungarian Uprising of 1956, but not in the invasion of Czechoslovakia in 1968. The support provided to the USSR in the former event influenced-according to some historians-the withdrawal of Soviet troops from the country in 1958.22 The refusal to participate in the latter and its condemnation led to an interesting reconfiguration in Romania's foreign policy.

Signs of Romania's distancing from Moscow appear at the beginning of the 1960s. An important step was the rejection of the plan initiated by Khrushchev and presented in Moscow to members of Comecon (the Council for Mutual Economic Assistance) on August 3-5, 1961, which would have forced Romania "to remain a provider of raw materials and to abandon its rapid industrialization program." 23 Although a follower of Leninist-Stalinist ideology, Gheorghe Gheorghiu-Dej, the then Communist leader, became much more popular among Romanians with a series of anti-Russian measures introduced gradually from 1963: the Maxim Gorki Institute in Bucharest was closed down, Russian was no longer a compulsory subject in schools, Russian street names were replaced, ARLUS (the Romanian Association for Strengthening the Bonds with the Soviet Union) and later the Cartea Rusă (Russian Book) media outlet were dissolved.

After taking power in 1965, Nicolae Ceaușescu continued his predecessor's National-Communist stance, one based on rapid industrialization and an autonomous foreign policy. It was probably by no accident that "Romania was the first country of the Eastern Bloc to establish diplomatic relations with West Germany in 1967, and not break off diplomatic relations with Israel after the Six-Day War." 24 Such gestures and especially Ceaușescu's refusal to take part in the Warsaw Pact troops' invasion of Czechoslovakia made Romania appealing to the West, and it was not long before the latter exploited this apparent crack in the Socialist Bloc. 25

\footnotetext{
${ }^{21}$ Until 1950, "tens and tens of works" dedicated to Stalin had already been written, "filled with the warmth of this love." See Anatol Vieru, "Succesele muzicii noastre în urma însuşirii principiilor Hotărârii CC al PC (b./bolșevic) asupra operei Marea prietenie de V. Muradeli [The Success of Our Music Following the Implementation of the Principles of the Decree of the Central Committee of the Bolshevik Communist Party on the Opera The Great Friendship by V. Muradeli]," Muzica 1 (1950): 15.

22 See Deletant, "România sub regimul comunist," 431.

${ }^{23}$ Ibid., 435.

24 Ibid., 439.

${ }^{25}$ Ibid., 446.
} 
This was also the context of US President Nixon's visit to Romania in August 1969, as well as Ceaușescu's visits to the US in October 1970 and to France in June 1970.

By and large, the 1960s were Romania's only period of relatively relaxed domestic policy and liberalization, with ideological control reaching its lowest point between 1965 and 1970. Western television series being broadcast on Romanian television and a Pepsi Cola factory opening in Constanța in 1967 are seen as the "ultimate symbol of concessions made to Western 'capitalism."' 26

Romanian music-in terms of both composition and international networking-enjoyed this wave of freedom moderately. A reasonably faithful reflection of this phase, whose developments become apparent when compared with the period of Sovietization, can be found in the policy adopted by Muzica, the regime's main means of communication in the field of music until the beginning of the 1990s.

A timid change in tone emerged in the mid-1950s. The polarization between "friendly countries" and "capitalist countries", as well as the omnipresence of the term "progressive" in relation to Western musicians endorsed in the East faded.

In the new political context, at least on a discursive level, the regime wanted to promote Romanian music "on all meridians," ignoring as much as possible the schism between the Socialist and the Capitalist Blocs. It was for reasons such as this that the George Enescu International Festival was created in 1958. Organized every three years, it became a good indicator of Romanian political developments. Despite some inherent ups and downs, it remains Romania's most important musical event to this day. The first five editions (1958, 1961, 1964, 1967 and 1970), starring first-class performers and orchestras, were illustrative of Romania's relative international openness (the first edition boasted such guests as Yehudi Menuhin, David Oistrakh, Halina Czerny-Stefańska, Nadia Boulanger, Monique Haas, Yakov Zak, Claudio Arrau, John Barbirolli, Carlo Felice Cillario and Carlo Zecchi).

The idea of Romanian music attracting notice worldwide was also a subject of Muzica's editorial policy, as its pages reported with patriotic pride the success that Romanian music enjoyed overseas, without overt political bias:

The universal acclaim in the press, from Moscow and Leningrad to Vienna, Paris, Helsinki, Athens, Rome, Washington or Philadelphia, bears witness to the fact that today our music has become and will become with each passing day more widely-known and more valued. ${ }^{27}$

Despite this professed internationalization, Romanian musicians' relations with colleagues abroad were frequently obstructed. Romanian composers were not allowed to participate in prestigious international festivals such as the Warsaw Autumn until

\footnotetext{
${ }^{26}$ Ibid., 443-444.

27 George Georgescu, "Să promovăm mai departe arta și cultura noastră nouă socialistă [Let us continue to promote our new socialist art and culture]," Muzica 12 (1962): 15.
} 
1965, as the then president of the Composers' Union Ion Dumitrescu "was opposed to the idea that the 'experimental music' of the younger generation should be known abroad." 28 There were also no copyright conventions to facilitate the travel of Romanian music abroad. An example of this was a refusal to collaborate with important Western publishing companies (e.g. Schott) interested in Romanian music. ${ }^{29}$

Despite the fact that it was difficult to have an "exchange of opinions or concepts with brothers beyond the 'iron curtain"' Romanian music took quite a step back from socialist realism, and quite a step forward on its way toward finding its own voice. In addition to the "series of scores in which contemporary Romanian music writing is grounded, new original systems take shape, formulated in important studies. This leads to a coalescing of aesthetic alternatives which, in the following decades, would turn out to be just as 'modern' as those from other parts of the world." 30

It was not until 1968-1970 that ideological control clearly slackened, and this happened, symbolically, in relation with the impact of the 1968 moment (essentially the phase of intensified relations between several Romanian musicians and the West). Composer Anatol Vieru's presence in Washington and New York, and musicologist Octavian Lazăr Cosma's ${ }^{31}$ study trip to the US took place in the context of Romania's new high-level political relations with the US: President Nixon's visit to Bucharest (1969), followed by Ceausescu's visit to Washington (1970). (It is, perhaps, ironic that the two musicians, ultimately famous figures in Romanian composing and musical historiography, had studied in Moscow and Leningrad, respectively.) Zeno Vancea's presence in the Federal Republic of Germany in 1968 for a series of conferences was a consequence of the diplomatic relations Romania had established with West Germany a year earlier. Again, Ceaușescu's visit to France brought a wave of Romanian music to French radio. ${ }^{32}$ These events, as well as others reflected in Muzica, ${ }^{33}$ suggest a more coherent attempt at internationalization.

\footnotetext{
${ }^{28}$ Valentina Sandu-Dediu, Muzica românească între 1944-2000 [Romanian music between 1944-2000] (Bucharest: Editura Muzicală, 2002), 27.

${ }^{29}$ Ibid., 26-28.

${ }^{30}$ Ibid., 28.

31 Zeno Vancea, Anatol Vieru, "Muzica românească în context mondial - convorbire cu Zeno Vancea și Anatol Vieru [Romanian Music in an International Context - A Conversation with Zeno Vancea and Anatol Vieru]," Muzica 4 (1968): 20-23; Octavian Lazăr Cosma, "Itinerar muzical american [American musical itinerary]," Muzica 6 (1970): 37-42.

32 See Radu Gheciu, "Cu prilejul vizitei tovarășului Nicolae Ceaușescu, Președintele Consiliului de Stat al R.S. România în Franța: Muzică românească la posturile franceze de Radio [On the occasion of the visit to France of vomrade Nicolae Ceaușescu, president of the State Council of the Socialist Republic of Romania: Romanian music on French airwaves]," Muzica 8 (1970): 4.

${ }^{33}$ See Alfred Hoffman, "Vizită artistică în Grecia [Artistic visit to Greece]," Muzica 11 (1970): 28-32; Dumitru Bughici, "Note de călătorie (în Italia și RFG) [Travel notes (from Italy and the Federal Republic of Germany)]," Muzica 11 (1970): 32-33; Smaranda Oțeanu, "Secvențe muzicale
} 
With regard to the relative freedom that the Romanian music press of the time enjoyed, an international survey on "The pathways of contemporary music" 34 is iconic, registering relaxed ideological opinions of several Western composers. The question "How do you view the issue of national character in the arts?"-one of the clichés and obsessions of Romanian musicology—received such answers as: "To be nationalist per se is just as useless as to abstractly wish to be universal" (Thomas Marco, Madrid); "Music is an international art" (Rolf Liebermann, Hamburg); "Esperanto is nevertheless not a language [...]. Eskimos composing in the Neapolitan style are ridiculous" (Werner Egk, Munich). ${ }^{35}$

\section{Phase 3}

Paradoxically, Romania's assumed external autonomy was counterbalanced by a disastrous, nationalist-isolationist domestic policy. Through the so-called July Theses of 1971, Ceaușescu imposed a new version of socialist realism under the name of "socialist humanism." Such measures taken in cultural policy, as well as the severe austerity to which Ceaușescu subjected the population in order to pay for the country's foreign debt, led Romania to a state of unprecedented isolation, especially in the 1980s. The fact that, for instance, Gorbachev's perestroika and glasnost reforms were seen by the Romanian leader as concessions made to the "international enemy of the people (capitalism)" 36 is illustrative of the nature of Romania's schizoid position.

With the July Theses, Romanian culture, and Romanian music with it, entered a process of Neo-Stalinization, wherein the cult of Ceaussescu's personality became more and more pronounced. Measures were taken to align musical life to the new commandments: "politically engaged art" in the long term is called for, designed to support the building of Socialism and Communism in the country, while dalliances with the experimental, the avant-garde or the mathematical were criticized. ${ }^{37}$

Iugoslave [Yugoslav musical reports]," Muzica 11 (1970): 35-37; Theodora Albescu, "Vara muzicală de la Taormina [Musical summer in Taormina]," Muzica 11 (1970): 37-39.

${ }^{34}$ Iosif Sava, "Anchetă internațională: Drumurile muzicii contemporane [International survey: The pathways of contemporary music]," Muzica 4 (1968): 1-9.

${ }^{35}$ Ibid., 2, 4, 5.

${ }^{36}$ Deletant, "România sub regimul comunist," 468.

37 See Nicolae Călinoiu, "Referatul prezentat de tov. Nicolae Călinoiu, directorul Direcției Muzicii din Consiliul Culturii și Educației Socialiste, la consfătuirea din 12 august 1971, privind repertoriul instituțiilor muzicale de spectacole și concerte pe stagiunea 1971-72 [Report presented by Comrade Nicolae Călinoiu, head of the Music Section of the Council of Socialist Culture and Education, at the gathering of August 12,1971, with regards to the repertoire of the musical institutions for shows and concerts for the 1971-1972 season]," Muzica 9 (1971): 1-10. 
In the scholarly press, articles debating Romanian music in an ideological key exponentially multiplied.

The artistic output of Nicolae Ceaușescu's new friends began to be popularized-such as, for instance, a work about the Korean fight against Japanese invasion performed by the Pyongyang Opera Ensemble:

Through the revolutionary opera The Sea of Blood, a collective work based on the national Korean epic of the same title [...], our audiences learned about the emotional hues of a sensibility, engendered by a genuinely mystical love of country and freedom, belonging to a people which will find neither rest nor complete happiness until peace and justice shield human fate worldwide. ${ }^{38}$

The fact that such strange artistic productions served as a model for Ceaussescu appears all the more frightening in the context of the re-ideologization of Romanian music.

Significant for this isolationist phase is, for instance, the direction the George Enescu International Festival undertook, from the first editions' opulence to the evident decline beginning in 1973: the festival was shortened to one week, the instrumental competition was canceled, and international participation was reduced to the point that the festival almost became a local event. The 1985 edition was the bottom point in this regard, as it featured no less than 75 Romanian composers. Foreign participants were a minority, chosen among musicians untroubled by politics, who were probably very well remunerated and willing to unconditionally praise Romanian music or performers in the Romanian press. ${ }^{39}$ In the opening address, Nicolae Călinoiu, president of the Composers' Union, presented the Enescu Festival as a sort of spinoff of the national festival Cântarea României (Song of Romania). An expression of nationalist policy and the personality cult surrounding Ceaușescu, Cântarea României understated the importance of the professional musician, emphasizing instead music made by amateurs. Despite aggressive propaganda, Cântarea României's international visibility did not even match that of North Korean artistic productions:

The National Festival Cântarea României, a large-scale manifestation of work and creative production in which millions of talents in all fields participate, revealed more than once an exceptional musical potential which brought about a continuous rise of Romanian artistic life, contributing to the cultivation and the development of the Romanian people's cultural

\footnotetext{
38 George Sbârcea, "Turneul Ansamblului de operă din Phenian [The tour of the Pyongyang Opera Ensemble]," Muzica 4 (1972): 26-27.

39 "Din opiniile oaspeților străini la festival [A sample of the opinions of foreign guests at the festival]," Muzica 10 (1985): 7-8.
} 
traditions, to enriching the universal cultural patrimony, obtaining as such a well-deserved international prestige. In this artistic context [emphasis added], the $10^{\text {th }}$ edition of the George Enescu International Festival brings together the country's creative and performing forces, joined by ensembles and personalities from all over the world. ${ }^{40}$

During all three important phases in Communist Romania's foreign (and domestic) policy, the fact that musical life was subject to the party's strict control remains an unquestionable reality. Romania's sometimes better, sometimes less inspired performance in the part it played in the Cold War had, during these four decades, a decisive impact on the development of Romanian music and on its international visibility in particular. It was one of the undeniably ill-fated marks of Communist totalitarianism.

${ }^{40}$ Călinoiu, "Referatul prezentat de tov. Nicolae Călinoiu,” 2. 


\section{References:}

Albescu, Theodora. "Vara muzicală de la Taormina." Muzica 11 (1970): 37-39.

Bughici, Dumitru. "Note de călătorie." Muzica 11 (1970): 32-33.

Călinoiu, Nicolae. "Referatul prezentat de tov. Nicolae Călinoiu, directorul Direcției Muzicii din Consiliul Culturii și Educației Socialiste, la consfătuirea din 12 august 1971, privind repertoriul instituțiilor muzicale de spectacole și concerte pe stagiunea 1971-72." Muzica 9 (1971): 1-10.

Cosma, Octavian Lazăr. "Itinerar muzical american." Muzica 6 (1970): 37-42.

Cristian, Vasile. "Soli ai muzicii din țările prietene." Muzica 9 (1952): 83-86.

Deletant, Dennis. "România sub regimul comunist (decembrie 1947-decembrie 1989)." In Istoria României, edited by Mihai Bărbulescu, Dennis Deletant, Keith Hitchins, Șerban Papacostea, Pompiliu Teodor, 407-480. Bucharest: Editura Corint, 2012.

"Din alte țări." Muzica 2 (1953): 76-77.

"Din opiniile oaspeților străini la festival." Muzica 10 (1985): 7-8.

Georgescu, George. "Să promovăm mai departe arta și cultura noastră nouă socialistă." Muzica 12 (1962): 15.

Gheciu, Radu. "Cu prilejul vizitei tovarășului Nicolae Ceaușescu, Președintele Consiliului de Stat al R.S.România în Franța: Muzică românească la posturile franceze de Radio." Muzica 8 (1970): 4.

Gheorghiu, Virgil. "Impresii din Republica Democrată Germană.” Muzica 12 (1952): 147-149.
Hoffman, Alfred. "Vizită artistică în Grecia." Muzica 11 (1970): 28-32.

Jerea, Hilda. "Festivalul muzicii bulgare." Muzica 9 (1952): 97-103.

Mendelsohn, Alfred. "Impresii din Praga." Muzica 9 (1952): 104-106.

Oțeanu, Smaranda. "Secvențe muzicale Iugoslave." Muzica, 11 (1970): 35-37.

Sandu-Dediu, Valentina. Muzica românească între 1944-2000. Bucharest: Editura Muzicală, 2002.

"Săptămâna Muzicii Românești." Muzica 5 (1952): 20.

Sava, Iosif. "Anchetă internațională: Drumurile muzicii contemporane." Muzica 4 (1968): 1-9.

Sbârcea, George. "Turneul Ansamblului de operă din Phenian." Muzica 4 (1972): 26-27.

Solovyov-Sedoi, Vasily Pavlovich. "Cuvântarea compozitorului V.P. SolovievSedoi ținută în ședința din 29.IX.1951 a Plenarei Uniunii Compozitorilor din R.P.R." Muzica 5 (1952): 62-65.

Stalin, Joseph Vissarionovich. "Răspunsurile tovarăşului I. V. Stalin la întrebările primite din partea corespondentului diplomatic al lui New York Times, James Reston, la 21 decembrie 1952." Muzica 12 (1952): 9.

Vancea, Zeno, Anatol Vieru. "Muzica românească în context mondial - convorbire cu Zeno Vancea și Anatol Vieru." Muzica 4 (1968): 20-23.

Vescan, Mauriciu. "Aspecte din viața muzicală a capitalei Uniunii Sovietice." Muzica 12 (1952): 143-146. 
Vieru, Anatol. "Succesele muzicii noastre în urma însușirii principiilor Hotărârii CC al PC (b./bolșevic) asupra operei Marea prietenie de V. Muradeli." Muzica 1 (1950): $10-17$.
Zakharov, Vladimir Grigoryevich. "Cuvântarea compozitorului V.G. Zaharov ținută în ședința din 28.IX.1951 a Plenarei Uniunii Compozitorilor din R.P.R." Muzica 5 (1952): 59-61. 